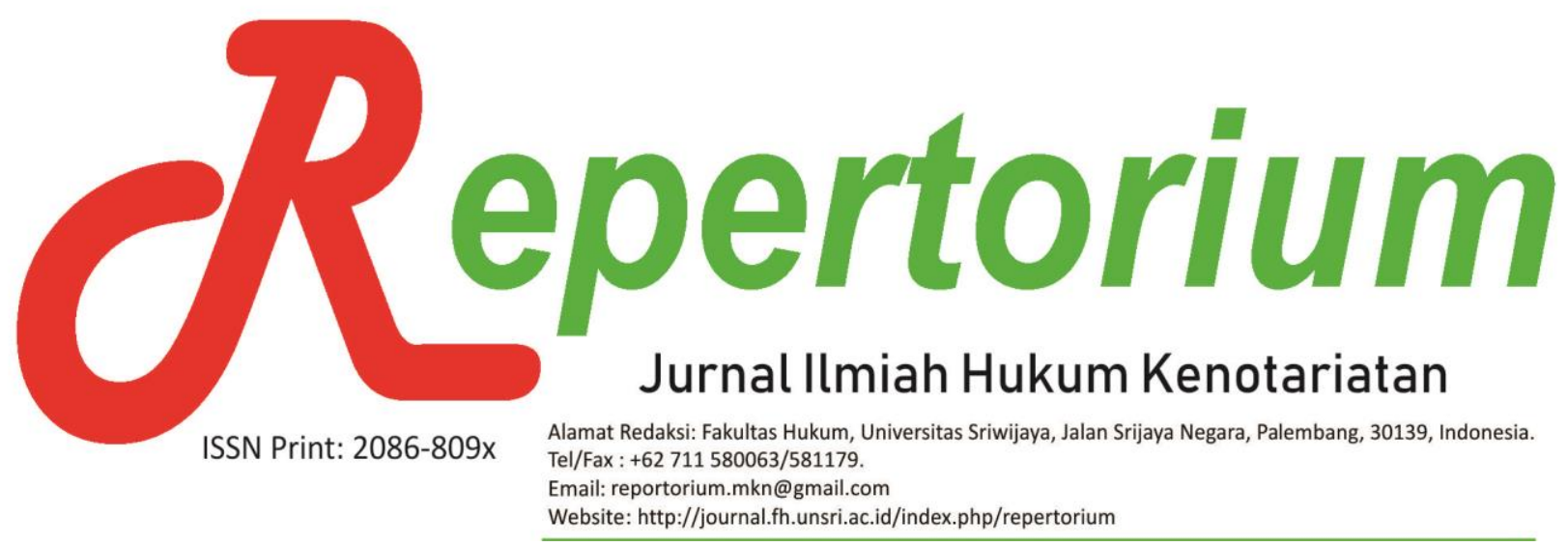

\title{
PENERAPAN KEWENANGAN PENGAWASAN MAJELIS PENGAWAS DAERAH (MPD) TERHADAP PELAKSANAAN CUTI NOTARIS DI KOTA PALEMBANG
}

\author{
Ponira *
}

\begin{abstract}
Abstrak: Artikel yang berjudul "Penerapan Kewenangan Pengawasan Majelis Pengawas Daerah (MPD) Terhadap Pelaksanaan Cuti Jabatan Notaris di Kota Palembang”, bertujuan untuk menganalisis tentang bagaimana prosedur dan apa yang menjadi pertimbangan dari MPD) dalam pemberian izin cuti jabatan Notaris, apa yang menjadi batas pengawasan MPD terhadap pelaksanaan cuti jabatan Notaris di kota Palembang, serta bagaimana bentuk pengawasan dan pemeriksaan yang dilakukan oleh MPD terhadap pelaksanaan cuti jabatan Notaris di Kota Palembang. Hasil dari penelitian ini yaitu: (1)Prosedur pelaksanaan cuti jabatan Notaris terkhusus dikota Palembang sebagaimana ketentuan yang ada dalam peraturan perUndang-Undangan yang berlaku, namun dalam proses pelaksanaan cuti ada hak dan kewajiban dari seorang Notaris yang tidak terpenuhi sebagaimana diatur dalam pasal 32 UU Jabatan Notaris yaitu tentang serah terima protokol jabatan dan dalam hal pemberian izin cuti jabatan kepada Notaris sejauh ini tidak ada tolak ukur khusus atas batasan-batasan alasan pengajuan permohonan cuti tersebut. ;(2) dalam hal batasan pengawasan MPD dalam pelaksanaan cuti jabatan sejauh ini penerapan wewenang pengawasan terhadap pelaksanaan cuti jabatan tidak ada, pengawasan hanya dilakukan pada pelaksanaan jabatan Notaris, yang mana saat tengah melaksanakan cuti seorang Notaris di anggap bertindak atas nama dirinya pribadi bukan dalam jabatannya sebagai pejabat umum (Notaris). ;(3)adapun bentuk pengawasan serta pemeriksaan yang dilakukan oleh MPD terhadap pelaksanaan cuti jabatan Notaris di Kota Palembang sejauh ini tidak ada tindakan khusus sebagai implementasi dari kewenangan MPD.
\end{abstract}

Kata kunci: Majelis Pengawas Daerah (MPD); Cuti Notaris; Penerapan Kewenangan.. 
* Magister Kenotaristan Fakultas Hukum Universitas Sriwijaya

\section{LATAR BELAKANG}

Dalam pasal 1 ayat (1) Undang-Undang nomor 02 tahun 2014 yang merupakan perubahan atas Undang-undang nomor 30 tahun 2004 tentang Jabatan Notaris menyebutkan bahwasannya "Notaris adalah pejabat umum yang berwenang membuat akta autentik dan memeiliki kewenangan lainnya sebagaimana dimaksud dalam Undang-undang ini atau berdasarkan undang-undang lainnya". Sebagai Pejabat Umum Notaris memiliki peranan sentral dalam menegakkan hukum di Indonesia, Notaris sebagai suatu jabatan yang karna jabatan tersebut telah membentuk suatu organisai berarti Notaris merupakan suatu komunitas ilmiah yang secara sosiologis, ekonomis, politis serta psikologis berada dalam stratifikasi yang relative lebih tinggi di antara masyarakat pada umumnya,Notaris sebagai pejabat umum artinya Negara telah memberikan kepercayan kepada seorang Notaris tersebut untuk menjalankan tugas Negara dalam bidang hukum peredata, yaitu pembuatan akta yang mempunyai kekuatan pembuktian yang sempurna dan seorang Notaris juga telah menjadi salah satu pejabat Negara yang diberikan kepercayaan penuh oleh semua pihak

1 Undang-undang nomor 2 tahun 2014 pembaruan atas undang-undang nomor 30 tahun 2004 Tenytang Jabatan Notaris yang telah atau menggunakan jasannya. Dengan kewenangan yang sedemikian besar maka seorang Notaris dalam pelaksanaan jabatannya diatur oleh Undang-Undang dan peraturan yang terkait serta di awasi sebagaimana ketentuan perUndang-Undangan yang mengatur. Dalam hal pelaksanaan jabatannya Notaris diawasin oleh Menteri yang dalam pelaksanaan pengawasannya Menteri Hukum dan Hak Asasi manusia membentuk majelis pengawas, yang dalam fungsi danperanannya dibagi menjadi 3 (tiga) yakni; Majelis Pengawas Daerah (MPD), Majelis Pengawas Wilayah (MPW), Majelis pengawas Pusat (MPP) yangmana masing-masing memiliki tugas dan batasan kewenangannya tersendiri sebagaimana yang telah ditentukan oleh Undang-Undang Jabatan Notaris (UUJN) dalam Pasal 69, Pasal 73, dan Pasal 77. Majelis pengaws ini dalam wewenangnya "mengawasi" tidak hanya dalam pelaksanaan jabatan Notaris akan tetapi pada semua tindak tanduk dari seorang Notaris baik dalam pelaksanaan tugas jabatan begitupun dalam kesehariannya. Dalam Undang-Undang Jabatan Notaris (UUJN) tidak hanya menjelaskan tentang kewajiban, kewenangan, dan larangan bagi seorang Notaris akan tetapi UUJN juga turut mengatur tentang apa yang menjadi hak dari seorang Notaris tersebut yakni hak untuk melaksanakan Cuti jabatan yangmana UUJN juga telah turut 
mengatur tentang prosedur pelaksanaan cuti jabatan itu sendiri. Sebagaimana dalam Pasal 25 UUJN menyebutkan;

Pasal 25:

(1) Notaris mempunyai Hak cuti.

(2) Hak cuti sebagaimana dimaksud pada ayat (1) dapat diambil setelah Notaris menjalankan jabatan selama 2(dua) tahun.

(3) Selama menjalankan Cuti Notaris wajib menunjuk seorang Notaris Pengganti.

Selanjutnya dalam pasal 27 UUJN menjelaskan tentang prosedur pengajuan permohonan cuti yangmana bunyi dari pasal tersebut yaitu;

Pasal 27 UUJN;

(1) Notaris mengajuka permohonan cuti secara tertulisdisertai penunjukan Notaris Pengganti.

(2) Permohonan cuti sebagaimana dimaksud dalam ayat (1) diajukan kepada pejabat yang berwemamh, yaitu:

a. Majelis Pengawas Daerah, dalam hal jangka waktu cuti tidak lebih dari 6(enam) bulan;

b. Majelis Pengawas Wilayah, dalam hal jangka waktu cuti lebih dari 6(enam) bulan sampai dengan 1(satu) tahun; atau

c. Majelis Pengawas Pusat, dalam jangka waktu cuti lebih dari 1(satu) tahun.
Berdasarkan pada penjelasan pasal 27 diatas dapat disimpulkan bahwasannya dalam hal mengawasi proses perolehan Hak jabatan Notaris yakni cuti setiap majelis pengawas baik tingkat Daerah, Wilayah, Pusat mempunyai tanggungjawab batasannya masing-masing. dalam hal penerapan pengawasan dari majelis pengawas yakni pada syarat dan prosedur permohonan cuti itu sendiri.

Namun dalam praktek lapangan nyatanya ada saja Notaris yang eninggalkan wilayah jabatannya tanpa mengajukan permohonan cuti sebelumnya, dan Notaris bersangkutan meninggalkan wilayah jabatannya lenih dari 7 (tujuh) hari kerja yang berdasarkan ketentuan dalam Pasal 17 hurup b dengan jelas menyebutkan bahwasannya seorang Notaris dilarang meninggakan wilayah jabatannya selama 7 (tujuh) hari berturutturut tanpa mengajukan permohonan cuti jabatan.

Berdasarkan uraian di atas maka rumusan masalah adalah sebagai berikut;

1. Apa saja yang diawasi oleh Majelis Pengawas Daerah (MPD) dalam pelaksanaan cuti Notaris di kota Palembang?

2. Bagaimana prosedur dan pertimbangan Majelis Pengawas Daerah (MPD) 
dalam pemberian cuti kepada Notaris?

3. Bagaimana bentuk pengawasan dan pemeriksaan yang dilakukan oleh Majelis Pengawas Daerah (MPD)?

\section{METODE}

Teori Kepastian Hukum

Utrecht membedakan antara penetapan yang sah dengan penetapan yang mempunyai kekuatan hukum (rechtsgeldig dan rechtskracht) dengan mentafsir pengertian yang diberikan oleh Dr Stellinga: "Bahwa sahnya suatu penetapan adalah suatu penilaian hukum sedang kekuatan hukun dari suatu penetapan menunjuk kepada akibatakibat sebagai pengaruh dari bekerjanya hukum, penetapan itu sah, kalau ia sudah dapat diterima sebagai bagian dari tertib hukum, sedang penetapan itu mempunyai kekuatan hukum, kalau ia telah dapat memberikan pengaruhnya dalam pergaulan hukum. ${ }^{2}$ Dalam teori kepastian hukum yang dikemukakan oleh Ultrecht ini menegaskan, bahwasannya suatu penetapan hukum dapat menciptakan suatu ketertiban pelaksanaan tugas dan wewenang jabatan dari semua instansi yang berkewajiban memberikan pelayanan kepada semua lapisan masyarakat sebagai pengguna jasa dari suatu profesi tertentu, diantaranya jasa

\footnotetext{
${ }^{2}$ Amrah Muslimin, 1998, Beberapa Azas-azas dan Pengertian Pokok Tentang Administrasi dan Hukum Administrasi, Bandung, Alumni, hlm.132.
}

Notaris selaku pejabat yang berwenang memberikan pelayanan hukum dan menciptakan suatu alat bukti autentik bagi para pihak selaku pengguna jasa.

Teori Kewenangan

Tindakan pemerintah merupakan instrument yang menghubungkannya dengan kehidupan bersama anggota masyarakat, yang menurut ulrecht dapat berupa tindakan atau perbuatan hukum (rechtshandelingen) dan tindakan yang bukan hukum, yang disebutnya dengan tindakan nyata (feitelike handelingen). Van poelje, seperti dikutip Kuntjuro Purbropranoto mengemukakan bahwa rechtshandeling door de overhead in haar bestuurfunctie verricht (tindakan hukum merupakan tindakan yang dilakukan penguasa dalam menjalankan fungsi pemerintah), dan dimaksud untuk menimbukan akibat hukum dibidang Hukumn Administrasi.

Berdasarkan pendapat para ahli tentang arti dari terori kewenangan ini, maka dengan demikian dapat dipahami jikasannya kewenangan mengatur serta mengawasi yang dimiliki oleh suatu instansi dalam pemerintahan itu ada karna tujuan mengatur dan memperbaiki suatu system kerja dari instansi tertentu demi terciptanya keselarasan dalam setiap tindakan yang dilakukan dengan peraturan-peraturan hukum yang ada.

Teori Pengawasan 
Pengertian pengawasan adalah adalah suatu proses menetapkan ukuran kinerja dan pengambilan tindakan yang dapat mendukung pencapaian hasil yang diharapkan sesuai dengan kinerja yang telah ditetapkan sebelumnya.

Menurut George $\mathrm{R}$ terry pengawasan yaitu suatu fungsi manajemen yang mana sangat berkaitan dengan suatu pencapaian atas tujuan tertentu dari sebuah Organisasi.Dan karena hal demikianlah dalam suatu organisasi ataupun instansi tententu sangatlah penting adanya pengawasan. ${ }^{3}$ Berdasarkan teori ini, sebagaimana jika di hubungkan dengan tindakan Majelis Pengawas Daerah yang melakukan pengawasan secara administratif kepada pelaksanaan cuti jabatan Notaris guna meminimalisir setiap kesalahan yang mungkin pernah ada sebelumnya dan bertujuan untuk mencegah terjadinya penyimpangan-penyimpangan yang berakibat menciptakan suatu pelanggaran hukum.

Teori Tanggungjawab

Notaris sebagai Pejabat Umum (openbaar ambtenaar) yang berwenang membuat akta otentik dapat dibebani tanggung jawab atas perbuatannya sehubungan dengan pekerjaannya dalam membuat akta tersebut. Ruang lingkup pertanggung jawaban Notaris meliputi

${ }^{3}$ George R Terry, "Dasar-dasar Manajemen", 2016., Jakarta., Bumi Aksara., hlm.253 kebenaran materil, Nico membedakannya menjadi: ${ }^{4}$

1.1. Tanggung jawab Notaris secara perdata atas akta Yang di buatnya.

1.2. Tanggung Jawab Notaris dalam menjalankan jabatannya berdasarkan kode etik notaris.

Jenis Penelitian yang digunakan penulis dalam penulisan tesis ini yaitu Penelitian Hukum Normatif yang di dukung dengan Data Empiris. Yang menggunakan Teknik Pendekatan yakni Pendekatan perundang-undangan (statute approach) dan penelitian murni (pure research. Yangmana sumber Bahan Hukumnya yaitu, Data Sekunder (bahan hukum yang erat hubungannya dengan bahan Hukum Primer) yang menjelaskan tentang bahanHukum Primer dan Tersier

\section{ANALISIS DAN DISKUSI}

Prosedur dan pertimbangan Majelis Pengawas Daerah (MPD) dalam pemberian cuti kepada Notaris

Menurut Pasal 15 Peraturan Menteri Hukum dan Hak Asasi Manusia Nomor 25 tahun 2014 yang mana telah diperbarui dengan Peraturan Menteri Hukum dan Hak Asasi Manusia Nomor 62 tahun 2016 Tentang Syarat dan Tata Cara Pengangkatan, Perpindahan, Pemberhentian dan Perpanjangan Masa

\footnotetext{
${ }^{4}$ Nico, 2003, Tanggung Jawab Notaris Selaku Pejabat Umum, Center for Documentation and of Business Law Yogyakarta, hlm 34.
} 
Jabatan Notaris, selaras dengan ketentuan pada pasal 27 Undang-Undang Jabatan Notaris. Notaris dapat mengajukan permohonan cuti dengan memenuhi semua prosedur yang ada dengan ketentuan bahwa Notaris tersebut telah melaksanakan jabatan sebagaimana seharusnya yakni Notaris telah melaksanakan jabatannya dengan jangka waktu paling singkat 2 (dua) tahun dan belum memenuhi jumlah waktu cuti yaitu 12 (dua belas) tahun. Sebagaimana ketentuan dalam pasal 27 ayat (2) Undang-Undang Jabatan Notaris menyebutkan bahwa permohonan cuti diajukan kepada pejabat yang berwenang yakni Majelis Pengawas Daerah (MPD) dalam hal pemberikan izin cuti yang diajukan oleh Notaris untuk jangka waktu tidak lebih dari 6 (enam) bulan, Majelis Pengawas Wilayah (MPW) dalam hal pemberian izin cuti untuk jangka waktu lebih dari 6 (enam) bulan sampai dengan 1 (satu) tahun dan Majelis Pengawas Pusat (MPP) dalam hal pemberian izin cuti untuk jangka waktu lebih dari 1 (satu) tahun.___Adapun prosedur pengajuan cuti sebagaimana diatur dalam pasal 27 ayat (1), (2) dan ayat (3) Undang-Undang jabatan Notaris yang bunyinya: ${ }^{5}$

Pasal 27 UUJN:
(1) Notaris mengajukan permohonan cuti secara tertulis disertai usulan penunjukan Notaris Pengganti.

(2) Permohonan cuti sebagaimana dimaksud pada ayat (1) diajukan kepada pejabat yang berwenang, yaitu:

1. Majelis pengawas Daerah, dalam jangka waktu cuti tidak lebih dari 6(enam) bulan;

2. Majelis Pengawas Wilayah, dalam jangka waktu cuti lebih dari 6(enam) bulan sampai dengan 1(satu) tahun; atau

3. Majelis pengawas pusat dalam jangka waktu lebih dari 1(satu) tahun.

(3) Permohonan cuti dapat diterima atau ditolak oleh pejabat yang berwenang memberikan izin cuti.

Berdasarkan pasal 27 diatas, jelas disebutkan prosedur pengajuan cuti bagi Notaris, dan dalam prosedurnya pejabat yang berwenang terlebih dahulu akan memeriksa setiap permohonan yang diterima, majelis tidak hanya memeriksa pada kelengkapan berkas permohonan

5 Undang-Undang Jabatan Notaris No.30 Tahun 2004 yang mana telah dirubah dengan Undang-undang Nomor 2 Tahun 2014. 
cuti saja akan tetapi juga pada alasan pengajuan permohonan tersebut.

Selanjutnya pejabat yang berwenang memberikan izin cuti akan mengeluarkan surat penetapan cuti dan penunjukan Notaris Pengganti dalam jangka waktu paling lama 14 (empat belas) hari terhitung sejak tanggal pengajuan permohonan, sebelum menjalankan jabatannya Notaris pengganti wajib mengucapkan sumpah atau janji menurut agamanya di hadapan Menteri atau pejabat yang ditunjuk, lafal sumpah atau janji sebagaimana dimaksud pada pasal 8 ayat (4) sesuai dengan peratutan perundang-undangan. Adapun hak dan kewajiban dari seorang Notaris sebagaimana diatur dalam pasal 32 Undang-Undang jabatan Notaris yakni Notaris yang akan melaksanakan cuti Jabatan, pada saat pengangkatan cuti seorang Notaris, berdasarkan ketentuan Undang-Undang disaat yang sama dilakukan serah terima Protokol oleh Notaris kepada Notaris Pengganti yang selanjutnya akan dilakukan kembali serah terima protokol jabatan pada saat masa cuti berakhir, serah terima protokol jabatan tersebut dibuatkan berita acara sebagai tembusan kepada Majelis Pengawas Wilayah (MPW) yang sebelumya di sampaikan terlebih dahulu kepada Majelis Pengawas Daerah (MPD).
Dasar pertimbangan pemberian izin cuti kepada Notaris

Jika dilihat pada pasal 27 ayat (3) yang bunyinya "permohonan cuti dapat diterima atau ditolak oleh pejabat yang berwenang memberikan izin cuti”, Dalam hal ini Majelis Pengawas Daerah sebagai pejabat yang berwenang untuk menerima, memeriksa dan mempertimbangkan suatu pengajuan cuti dari Notaris dalam jangka waktu tidak lebih dari 6 (enam) bulan maka Majelis Pengawas Darah (MPD) harus memeriksa terlebih dahulu semua berkas kelengkapan permohonan cuti dari seorang Notaris tersebut, untuk selanjutnya memutuskan apakah cuti tersebut dapat di kabulkan atau ditolak, penolakan permohonan cuti sebagaimana dimaksudkan secara teori dikarenakan dalam permohonan tersebut tidak terpenuhinya unsur-unsur dalam pasal 15 dan 16 Undang-Undang Jabatan Notaris, diantaranya:

1) Masa jabatan Notaris yang mengajukan permohonan cuti belum mencapai 2 (dua) tahun terhitung sejak melaksanakan sumpah jabatan Notaris;

2) Notaris yang bersangkutan telah menjalani cuti selama 12 (dua belas) tahun; atau;

3) Permohonan cuti yang diajukan tidak sesuai dengan ketentuan Pasal 36 ayat (2) yaitu tidak melengkapi 
dokumen-dokumen yang wajib untuk dilampirkan. ${ }^{6}$

4) Surat permohonan wajib dilampirkan dengan dokumen berupa:

1. fotokopi surat keputusan pengangkatan atau pindah sebagai Notaris yang disahkan oleh Notaris;

2. Fotokopi yang disahkan dari berita acara sumpah/janji sebagai Notaris;

3. Fotokopi surat yang menjadi dasar untuk cuti yang disahkan oleh Notaris;

4. Asli sertifikat cuti Notaris. ${ }^{7}$

Dalam penolakan permohonan cuti, ketentuan pada pasal 31 menyebutkan bahwa Majelis Pengawas Daerah (MPD), Majelis Pengawas Wilayah (MPW), Majelis Pengawas Pusat (MPP) selaku pejabat yang berwenang memberikan cuti akan mengeluarkan surat penolakan cuti disertai dengan alasan penolakan cuti itu sendiri. ${ }^{8}$ Namun dalam praktek lapangan, khususnya di kota Palembang sejauh ini belum pernah ada penolakan atas pengajuan permohonan cuti Notaris. dikarenakan semua prosedur terpenuhi dan semua alasan dapat diterima oleh

\footnotetext{
${ }^{6}$ Imelda Mouly Irianty, FH UI, 2011, Tinjauan Yuridis Mengenai Notaris Yang Cuti Diangkat Sebagai Pejabat Negara.

7 Ibid.,

8 Undang-Undang Jabatan Notaris Nomor 30 tahun 2004 sebagaimana telah diperbarui dengan Undang-Undang jabatan Notaris Nomoe 2 tahun 2014
}

Majelis. Secara tidak langsung dapatlah disimpukan bahwasannya tidak ada tolak ukur pasti tentang apa yang menjadi pertimbangan pemberian serta penolakan permohonan cuti Notaris terkhususnya di kota Palembang. ${ }^{9}$

Batas pengawasan Majelis Pengawas Daerah (MPD) dalam pelaksanaan cuti Notaris di kota Palembang.

Dilihat dari segi administrasi prosedur pengajuan cuti Notaris di kota Palembang dengan masa cuti yang tidak lebih dari 6 (enam) bulan secara prosedur permohonan diajukan kepada Majelis Pengawas Daerah (MPD) dalam praktek lapangan berjalan sesuai dengan ketentuan perundang-undangan yang berlaku, yang mana prosedur pengajuan cuti telah diatur dalam pasal 27 ayat (1) sampai dengan ayat (3) Undang-undang Jabatan Notaris yang bunyinya:

Pasal 27 UUJN:

(1) Notaris mengajukan permohonan cuti secara tertulis disertai usulan penunjukan Notaris Pengganti.

(2) Permohonan cuti sebagaimana dimaksud pada ayat (1) diajukan kepada pejabat yang berwenang, yaitu:

\footnotetext{
9 Hasil Wawancara langsung dengan Notaris Zulkifli Rassy SH., M.Kn selaku ketua Pengawas Daerah Notaris kota Plembang, yang juga anggota dari Majelis Pengawas Daerah kota Palembang pada tanggal 09 mei 2018.
} 
1. MPD, dalam hal jangka waktu cuti tidak lebih dari 6 (enam) bulan;

2. MPW, dalam hal jangka waktu cuti lebih dari 6 (enam) bulan sampai dengan 1 (satu) tahun; atau

3. MPP, dalam hal jangka cuti lebih dari 1 (satu) tahun.

(3) Permohonan cuti dapat diterima atau ditolak oleh pejabat yang berwenang memberikan izin cuti.

Dalam pelaksanaan cuti Notaris terkhusus di kota Palembang, jika dilihat dari prosedur pengajuan semua persyaratan terpenuhi dan peraturan yang ada tentang permohonan cuti juga telah dijalankan dengan baik, namun ada beberapa ketentuan perundang-undangan yang sejatinya menjadi hak dan kewajiban Notaris pada saat mengambil cuti dan setelah menjalankan cuti sering tidak terpenuhi, ${ }^{10}$ yakni ketentuan dalam pasal 32 Undang-Undang Jabatan Notaris yang mengatur tentang kewajiban Notaris saat mengambil cuti dan setelah pelaksanaan cuti yang mana bunyi dari pasal tersebut yaitu:

Pasal 32 UUJN:

(1) Notaris yang menjalankan cuti wajib menyerahkan Protokol Notaris kepada Notaris Pengganti.

10 Hasil Wawancara langsung dengan Notaris Zulkifli Rassy SH., M.Kn selaku ketua Pengawas Daerah Notaris kota Plembang, yang juga anggota dari Majelis Pengawas Daerah kota Palembang pada tanggal 09 mei 2018
(2) Notaris Pengganti menyerahkan kembali Protokol Notaris kepada Notaris setelah cuti berakhir.

(3) Serah terima sebagaimana dimaksud pada ayat (1) dan ayat (2) dibuatkan berita acara dan disampaikan kepada Majelis Pengawas Wilayah.

(4) Notaris yang melanggar ketentuan sebagaimana dimaksud pada ayat (1), ayat (2), dan ayat (3) dapat dikenai sanksi berupa:

1. peringatan tertulis;

2. pemberhentian sementara;

3. pemberhentian dengan hormat; atau

4. pemberhentian dengan tidak hormat.

Dalam pasal tersebut dengan tegas menjelaskan tentang hak dan kewajiban dari seorang Notaris pada saat mengambil cuti dan setelah pelaksanaan cuti itu sendiri, namun dalam prakteknya apa yang menjadi ketentuan pada pasal ini tidak dapat di implementasikan sebagaimana seharusnya. Berdasarkan prosedur pada saat majelis mengangkat cuti pada saat yang sama dilakukan serah terima protokol, dan setelah masa cuti berakhir dilakukan kembali serah terima protokol. Namun dalam praktek ketentuan pasal ini seakan sulit untuk di implementasikan dilapangan. Bukan karena tidak pernah mencoba untuk memperbaiki apa yang telah salah dalam pelaksanaan cuti tersebut, namun faktor kebiasaan dan faktor kepercayaan seakan menjadi suatu hal yang menghalangi 
penerapan dari ketentuan pasal ini. Zulkifli Rassy. S.H., M.H selaku ketua Pengawas Daerah Notaris yang juga merupakan anggota dari Majelis Pengawas Daerah (MPD) mengatakan, bahwa selaku anggota dari majelis pengawas yang mana sudah kurang lebih selama 3 (tiga) periode mengemban tanggungjawab tersebut apalagi saat ini dipercayakan sebagai ketua dari organisasi pengawas daerah yang mengontrol tahapan pengawas yang ditugaskan melakukan pengawasan terhadap pelaksanaan jabatan Notaris terkhusus di kota Palembang telah mencoba mengingatkan kepada semua jajaran majelis pengawas, baik kepada Majelis Pengawas Wilayah (MPW), Majelis Pengawas Pusat (MPP) namun sejauh ini terkesan tidak ada upaya memperbaiki untuk menciptakan perubahan atas pelanggaran yang telah menjadi kebiasaaan dalam praktek pelaksanaan cuti Notaris di lapangan. Sebagaimana hampir semua majelis pengawas mengemukakan pendapat selalu dengan penjelasan yang sama, karena hubungan baik antara Notaris yang sering kali mempengaruhi atas tidak dapat dilaksanakannya ketentuan dalam pasal 32 Undang-Undang Jabatan Notaris tersebut. ${ }^{11}$

11 Hasil Wawancara langsung dengan Notaris Zulkifli Rassy SH., M.Kn selaku ketua Pengawas Daerah Notaris kota Plembang, yang juga anggota dari Majelis Pengawas Daerah kota Palembang pada tanggal 09 mei 2018.
Batasan pengawasan Majelis Pengawas Daerah (MPD)

Kewenangan Majelis Pengawas Daerah (MPD) yang bersifat administratif dilaksanakan oleh ketua, wakil ketua, atau salah satu anggota, yang diberi wewenang berdasarkan keputusan rapat Majelis Pengawas Daerah. Selain melakukan pemeriksaan terhadap dugaan pelanggaran dan juga pengawasan dalam pelaksanaan tugas dan jabatan Majelis Pengawas Daerah (MPD) berwenang untuk memberikan izin cuti yang diajukan oleh Notaris untuk jangka waktu tidak lebih dari 6 (enam) bulan sebagaimana disebutkan dalam Pasal 27 ayat (2) huruf a,

Dalam hal pengajuan cuti tersebut diterima, fungsi Pengawasan dari Majelis Pengawas dalam hal ini Majelis Pengawas Daerah (MPD) yaitu tetap melakukan pengawasan kepada pelaksanaan jabatan Notaris namun bukan kepada Individual Notaris yang tengah melaksanakan cuti. Akan tetapi pengawasan di titik beratkan pada aktivitas kantor yang tengah dijalankan oleh Notaris Pengganti selama Notaris bersangkutan tengah menjalankan cuti. Ruang lingkup pengawasan Majelis Pengawas Daerah (MPD) sama halnya pengawasan pada pelaksanaan jabatan Notaris, sebagaimana ketentuan dalam pasal 33 ayat (2) yang menyebutkan bahwasannya "ketentuan yang berlaku bagi Notaris sebagaimana dimaksud dalam pasal 4, 15, 16, dan 17 berlaku 
bagi Notaris Pengganti dan pejabat sementara Notaris kecuali undangundang ini menentukan lain". Berdasarkan penjelasan pasal tersebut dengan tegas menyebutkan bahwasannya apa yang menjadi kewenangan, kewajiban serta larangan bagi Notaris dalam pelaksanaan tugas dan jabatannya turut menjadi kewenangan, kewajiban dan larangan dalam pelaksanaan tugas jabatan seorang Notaris Pengganti, dimana kewenangan tersebut akan berakhir ketika batas yang tercantum dalam surat jabatannya telah berakhir.

Bentuk pengawasan dan pemeriksaan yang dilakukan oleh Majelis Pengawas Daerah (MPD) dalam pelaksanaan cuti Notaris di kota Palembang.

Pasal 1 angka 1 Peraturan Menteri Hukum dan Hak Asasi Manusia Republik Indonesia Nomor M.02.PR.08 Tahun 2004, menegaskan yang dimaksud dengan Pengawasan adalah merupakan suatu kegiatan yang bersifat preventif dan kuratif termasuk kegiatan pembinaan yang dilakukan oleh Majelis Pengawas Terhadap Notaris. Majelis Pengawas Notaris yaitu satu-satunya instansi yang berwenang melakukan pengawasan, pemeriksaan dan menjatuhkan sanksi terhadap Notaris, yang mana obyek pengawasan dari majelis pengawas ialah Notaris, dan yang diawasi ialah tingkah laku dan prilaku Notaris dalam menjalankan Jabatannya, yang mana dalam menjalankan tugas dan wewenangnya Majelis Pengawas ini secara hirarki terbagi menjadi 3 tiga) yaitu Majelis Pengawas Daerah (MPD), Majelis Pengawas Wilayah (MPW), Majelis Pengawas Pusat (MPP) yang mempunyai tugas dan wewenang masing-masing.

Tugas dan wewenang Majelis Pengawas Daerah (MPD)

Pasal 1 ayat (7) peraturan Menteri Hukum Dan Hak Asasi Manusia Nomor 25 tahun 2014 yang mana telah dirubah dengan Peratauran Menteri Hukum dan Hak Asasi Manusia Nomor 62 tahun 2016 tentang Syarat dan Tata Cara Pengangkatan, Perpindahan, Pemberhentian dan Perpanjangan Masa Jabatan Notaris menyebutkan bahwasannya yang dimaksud dengan Majelis Pengawas Daerah atau selanjutnya disingkat MPD yaitu, "Majelis Pengawas Daerah (MPD) adalah suatu badan yang mempunyai kewenangan dan kewajiban untuk melaksanakan pembinaan dan pengawasan terhadap Notaris di tingkat kabupaten/kota”. Tugas Majelis Pengawas Daerah yaitu melaksanakan kewenangan sebagaimana dimaksud dalam pasal 70 dan 71 undang-undang nomor 30 tahun 2004 tentang jabatan Notaris dan dan pasal 13 ayat (3), pasal 14 , pasal 15, pasal $16 \mathrm{~b}$ dan pasal 17 peraturan Menteri hukum dan hak asasi manusia Republik Indonesia Nomor 
M.02.PR.08.10 tahun 2004 tentang tata cara pengangkatan anggota, pemberhentian anggota, susunan organisasi, tata kerja dan tata cara pemeriksaan Majelis Pengawas Notaris. $^{12}$

Dalam pelaksanaan kewajiban Majelis Pengawas Daerah (MPD) yang bersifat administratif dilaksanakan oleh ketua, wakil ketua, atau salah satu anggota, yang diberi wewenang berdasarkan keputusan rapat Majelis Pengawas Daerah (MPD), yang dimaksud dengan pengawasan oleh Majelis Pengawas Daerah (MPD) ialah suatu kegiatan yang bersifat preventif (kegiatan pencegahan) dan kuratif ( rangkaian kegiatan) termasuklah pula kegiatan pembinaan yang dilakukan oleh majelis pengawas terhadap suatu jabatan Notaris. ${ }^{13}$ Adapun tujuan dari Majelis Pengawas Daerah (MPD) dalam melakukan pengawasan yaitu untuk memberikan arah dan tuntunan bagi Notaris dalam menjalankan jabatan profesinya sebagai pejabat umum yang senantiasa meningkatkan profesionalisme dan kualitas kerjanya, sehingga dapat memberikan jaminan kepastian dan

12 Keputusan Menteri Hukum dan Hak Asasi Manusia Republik Indonesia Nomor M.39PW.07.10 Tahun 2004, bagian ke III tentang Tugas Majelis Pengawas Notaris.

13 Peraturan Menteri Hukum dan Hak Asasi Manusia Republik Indonesia nomor 25 tahun 2014 yang mana telah diperbarui dengan Peraturan Menteri Hukum dan Hak Asasi Manusia Republik Indonesia nomor 62 tahun 2016 . perlindungan hukum bagi penerima jasa Notaris dan masyarakat luas. ${ }^{14}$

Bentuk pengawasan Majelis Pengawas Daerah (MPD) terhadap pelaksanaan cuti jabatan Notaris di kota Palembang Adapun pengawasan yang dilakukan oleh Majelis Pengawas yaitu tidak sematamata hanya terbatas kepada pengawasan terhadap pelaksanaan tugas jabatan Notaris yang harus sesuai dengan Undang-Undang Jabatan Notaris, akan tetapi juga berlaku pada Kode Etik Notaris dalam hal ini kode etik jabatan Notaris bukan kode etik profesi dan juga terhadap tindak-tanduk ataupun prilaku kehidupan Notaris yang dapat menciderai keluhuran martabat jabatan Notaris. Dalam hal pengawasan Majelis Pengawas sebagaimana dimaksud dalam Pasal 67 ayat (5) Undang-Undang Jabatan Notaris, yaitu menunjukkan pada suatu hal yang sangat luas tentang apa yang menjadi ruang lingkup pengawasan yang harus dilakukan oleh Majelis Pengawas itu sendiri. Diantaranya, pengawasan terhadap pelaksanaan tugas jabatan Notaris dengan ukuran batasan sebagaimana telah diatur pada pasal 70 Undang-Undang Jabatan Notaris, dengan maksud semua ketentuan didalamnya yang mengatur tentang pelaksanaan tugas jabatan Notaris dapat dipatuhi oleh

\footnotetext{
14 Sukamta. S.H., M.H, dalam seminar "sosialisasi layanan kenotariatan bagi notaris dan calon Notaris oleh kantor wilayah kota Palembang" pada tanggal 03 Mei 2018.
} 
Notaris itu sendiri. Dan apabila terjadi pelanggaran, maka Majelis Pengawas dapat menjatuhkan sanksi kepada Notaris yang bersangkutan. ${ }^{15}$

Pemeriksaan Majelis Pengawas Daerah (MPD) terhadap jabatan Notaris di kota Palembang.

Sejalan dengan arti pengawasan, batasan pengawasan serta objek-objek yang diawasi sebagaimana telah dijelaskan sebelumnya, bahwasannya pengawasan menyeluruh yaitu suatu pengawasan yang ada untuk memperbandingkan sebenarnya, dan untuk mengevaluasi pelaksanaan kerja yang mana biasanya terjadi perbedaan antara ekspektansi dan performansi dalam prakteknya. ${ }^{16}$ Semua yang menjadi wewenang dari Majelis Pengawas Daerah (MPD) sejauh tentang pengawasan dan pemeriksaan semua berjalan sebagaimana ketentuan dalam Undang-undang yang mengatur tentang hal tersebut.

Berikutnya tentang proses pemeriksaan yang merupakan rangkaian dari proses pengawasan yang mana pemeriksaan merupakan tahap lanjutan dari suatu proses pengawasan, maka dari itulah Undang-undang telah mengatur tentang jangka waktu pemeriksaan secara rutin oleh Majelis Pengawas Daerah (MPD) atas pelaksanaan jabatan Notaris.

15 Habib Adjie., Sanksi Perdata dan Administratif terhadap Notaris sebagai Pejabat Publik., Bandung., Refika Aditama., hal.145

${ }^{16}$ George R Terry., Dasar-Dasar Manajemen., PT. bumi Aksara, Jakarta., hlm.236
Yang mana proses pemeriksaan rutin tersebut ada dan telah ditentukan waktu pemeriksaan oleh undang-undang yaitu pemeriksaan tersebut dilakukan setiap 1 (satu) tahun 1 (satu) kali, dan merupakan pemeriksaan secara preventif artinya suatu pemeriksaan yang dilakukan dengan tujuan untuk mengurangi ataupun memperbaiki sesuatu yang kurang baik atau suatu kesalahan dalam pelaksanaan jabatan Notaris. 17 Dalam hal pemeriksaan administratif atau suatu pemeriksaan rutin Notaris yang dilakukan oleh Majelis Pengawas Daerah (MPD) terhadap 223 (dua ratus dua puluh tiga) jumlah Notaris dikota Palembang yang proses pemeriksaan biasanya di lakukan terjadwal disetiap bulan Mei sampai dengan Agustus disetiap tahunnya. Majelis Pengawas Daerah (MPD) megirim tim pemeriksa yang terdiri dari 3 (tiga) orang anggota dan 1 (satu) orang sekretaris untuk segera melakukan pemeriksaan pada kantor Notaris yang dijadwalkan pada hari tertentu. $^{18}$

\footnotetext{
${ }^{17}$ Hasil wawancara dengan Dr.Ridwan.S.H., M.H selaku mantan anggota Majelis Pengawas Notaris tingkat kabupaten/kota, pada tanggal 20 April 2018.

18 Hasil Wawancara langsung dengan Notaris Zulkifli Rassy SH., M.Kn selaku ketua Pengawas Daerah Notaris kota Plembang, yang juga anggota dari Majelis Pengawas Daerah kota Palembang pada tanggal 09 mei 2018.
} 


\section{KESIMPULAN DAN SARAN}

Prosedur dan pertimbangan Majelis Pengawas Daerah dalam pemberian izin cuti terhadap Notaris, dilihat dari prosedur pengajuan cuti Notaris di kota Palembang dilaksanakan sebagaimana seharusnya ditetapkan dalam peraturan perundang-undangan yang berlaku. Namun dalam pelaksanaan cuti ada hal yang tidak terlaksana sebagaimana seharusnya diamanatkan dalam Undang-Undang, yakni pemenuhan hak dan kewajiban Notaris yang akan melaksanakan cuti sebagaimnana diatur dalam pasal 32 Undang-Undang Jabatan Notaris yaitu serah terima protokol Notaris. dalam hal pemberian izin cuti oleh Majelis Pengawas Daerah (MPD) sejauh ini tidak ada tolak ukur khusus atas batasanbatasan alasan pengajuan permohonan cuti tersebut, karena dalam prakteknya sampai degan saat ini belum ada permohonan cuti yang di tolak karena alasan pengajuan yang tidak diterima oleh Majelis Pengawas Daerah (MPD) terkhusus di kota Palembang.

Batasan pengawasan Majelis Pengawas Daerah (MPD) dalam pelaksanaan cuti Notaris di kota Palembang, dalam praktek penerapan wewenang pengawasan oleh Majelis Pengawas Daerah (MPD) terhadap pelaksanaan cuti Notaris itu sendiri tidak ada, sejauh ini pengawasan yang dilakukan hanya pada pelaksanaan jabatan Notaris semata dan hal itupun dilakukan hanya dalam bentuk pemeriksaan sebagaimana yang diamanatkan Undang-Undang, pengawasan dalam pelaksanaan cuti Notaris tidak dilakukan karena Notaris yang tengah menjalankan cuti bertindak atas nama individual atau atas nama diri pribadi bukan dalam jabatan sebagai pejabat Negara. Akan tetapi Majelis Pengawas Daerah tetap melakukan pengawasan yang mana obyek pengawasannya dialihkan kepada pelaksanaan jabatan yang diemban oleh Notaris Pengganti sebagai penerima protokol jabatan dari Notaris yang tengah menjalankan cuti tersebut.

Bentuk pengawasan dan pemeriksaan yang dilakukan oleh Majelis Pengawas Daerah (MPD) terhadap pelaksanaan cuti jabatan Notaris di kota Palembang, sejauh ini tidak ada tindakan khusus sebagai implementasi kewenangan pengawasan dari Majelis Pengawas Daerah (MPD) terhadap pelaksanaan cuti jabatan Notaris di kota Palembang. Namun dalam hal pemeriksaan yang mana merupakan rangkaian dari proses pengawasan, sejauh ini pemeriksaan yang dilakukan oleh Majelis Pengawas Daerah (MPD) yaitu merupakan rangkaian kegiatan (kuratif) pemeriksaan dalam rangka pencegahan (preventif) yang artinya suatu pemeriksaan yang dilakukan atas dasar tujuan memperbaiki kesalahan yang mungkin ada dan menjamin kepastian atas terimplementasinya semua 
peraturan jabatan yang berlaku, yang mana pemeriksaan dilakukan oleh Majelis Pengawas Daerah (MPD) setiap 1 (satu) tahun 1 (satu) kali sebagaimana ditentukan dalam pasal 70 huruf b Undang-Undang jabatan Notaris.

Dalam hal tidak terpenuhinya hak dan kewajiban Notaris pada saat pengambilan dan pelaksanaan cuti, sebagaimana diamanatkan oleh pasal 32 Undang-Undang jabatan Notaris tersebut dalam hal ini ketegasan dari Majelis Pengawas Daerah (MPD) sangatlah di utamakan, seharusnya Majelis Pengawasan Daerah dalam pelaksanaan tugas jabatan tidak boleh mengikutsertakan hubungan pribadi, baik itu kekerabatan ataupun pertemanan antara tim pemeriksa dengan obyek pemeriksaan itu sendiri .

Dalam praktek seharusnya Majelis Pengawas membentuk tim pemeriksa yang dalam hal ini bukan melakukan pemeriksaan atas Protokol Notaris akan tetapi pemeriksaan atas perilaku Notaris dan pelaksanaan jabatan Notaris, misalnya tentang keberadaan Notaris, kegiatan kantornya dan lain sebagainya yang mana tim tersebut melakukan pemeriksaan rutin minimal setiap 2 (dua) bulan sekali di setiap akhir bulan, karena dengan tindakan demikian diharapkan dapat mengontrol kegiatan Notaris dan membuat Notaris merasa benar-benar diawasi dalam pelaksanaan jabatan Notaris tersebut, dengan demikian dipastikan Notaris akan lebih hati-hati, dalam melakukan tindakan dan diharapkan dapat meminimalisir kesalahan dalam bentuk apapun.

\section{DAFTAR PUSTAKA}

\section{Buku}

Suratman, H. Philips Dillah. Metode Penelitian Hukum. Bandung: Alfabeta, 2012.

Sjaifulrachman. Aspek Pertanggungjawaban Notaris dalam Pembuatan Akta. Bandung: Mandar Maju , 2011.

Abdul Ghofur Ansori. Lembaga Kenotariatan Indonesia, Yogyakarta: UU Press, 2009.

Adjie Habib. Penafsiran Tematik Hukum Notaris Indonesia. Bandung: PT. Refika Aditama, 2015.

Adjie Habib. Hukum Notaris Indonesia. Bandung: Refika aditama, 2008.

Supriadi. Etika dan Tanggung Jawab Profesi Hukum Indonesia. Jakarta: Sinar Grafika, 2006.

Abdulkadir Muhammad. Hukum dan Penelitian Hukum. Bandung: PT.Citra Aditya, 2004.

Philipus M. Hadjon. Pengantar Hukum Perizinan.Jakarta:Rajawali Pers, 2003.

Amrah Muslimin. Beberapa Azas-azas dan Pengertian PokokTentang Administrasi dan Hukum Administrasi.Bandung: Alumni, 1998. 
Abdul Kadir Muhammad, Hukum dan Penelitian Hukum, Citra Aditya,Bandung, 2004

Andi Hamzah, Kamus Hukum, Ghalia Indonesia, Bandung, 2005

Achmad Ali, Menguak Tabir Hukum (Suatu Kajian Filosofis da Sosiologis), Toko Gunung Agung, Jakarta, 1996

Saiful Anwar, Sendi-Sendi Hukum Administrasi Negara, Glora Madani Press, Jakarta, 2004

George R Terry, Dasar-Dasar Menejemen, Bumi Aksara, Jakarta 2016

Tobing G.H.S. Lumban, Peraturan Jabatan Notaris, Erlangga, Jakarta, 1983

Ira Koesumawati dan Yunirman Rijan, Ke Notaris , Raih Asa Sukses, Jakarta, 2009

Sautro, Anke Dwi, 100 Tahun Ikatan Notaris Indonesia, Jati Diri Notaris Indonesia, Dulu, Sekarang, dan Dimasa Datang, Gramedia Pustaka Utama, Jakarta, 2008

Philipus M. Hadjon dkk, Pengantar Hukum Administrasi Indonesia ( Intro Duction To The Indonesian Administrative Law), Gajah Mada University Press, Yogyakarta, 2005

Dominikus Rato, Filsafat Hukum Mencari : Memahami HUkum, Laksbang Pressindo, Yogyakarta, 2010

Peter Mahmmud Marzuki, Pengantar Ilmu Hukum, Kencana, Jakarta, 2008
Riduan Syahran, Rangkuman Intisari Ilmu Hukum, Citra Aditya Bakti, Bandung, 1999

Cst Kansil, Christine S.T, dkk, Kamus Istilah Hukum, Pustaka Sinar Harapan, Jakarta, 2009

Bohari, Pengawasan Keuangar Nnrra a , Rajawali Pers, Jakarta, 1992

Sujanto, Beberapa Pengertian Dibidang Pengawasan, Ghalla Indonesia, Jakarta, 1986

\section{Peraturan Perundang-undangan}

Undang-Undang Nomor 2 Tahun 2014 Tentang Perubahan atas Undang-Undang Nomor 30 Tahun 2004 Tentang Jabatan Notaris.

Kitab Undang-Undang Hukum Perdata (KUH Perdata)

Peraturan Menteri Hukum dan Hak Asasi Manusia Republik Indonesia Nomor 62 Tahun 2016 yang merupakan Perubahan atas Peraturan Menteri Hukum dan Hak Asasi Manusia Republik Indonesia Nomor 25 Tahun 2014

\section{Internet}

http://inayahqueen.blogspot.co.id/2014/0 2/hi.html, diakses pada tanggal 31 januari 2018, pukul: 23.40 WIB

http://www.negarahukum.com/hukum/te oripengawasan.html,diakses pada tanggal 01 April 2018, Pukul : 22.00 WIB 


\section{Jurnal}

Nico. 2003. Tanggung Jawab Notaris Selaku Pejabat Umum.

Yogyakarta: Center for Documentation and of Business Law.

Andasasmita, Komar, 1990 Notaris II Contoh Akta Otentik Dan Penjelasannya, Ikatan Notaris Indonesia, Bandung

Yogi priambodo,Gunarto, 2017 Tinjauan Terhadapan Kode Etik Jabatan Notaris Dikabupaten Purbalingga, Jurnal Akta, Volume 4,3 September 2017

Nurmayani, 2009, Hukum Administrasi Daerah Bandar Lampung

\section{Wawancara}

Hasil wawanacara langsung dengan Notaris Zulkifli Rassy, S.H., M.Kn yang juga anggota dari Majelis Pengawas Daerah pada tanggal 9 Mei 2018.

Hasil wawancara langsung dengan Dr.Ridwan.S.H., M.H selaku mantan anggota Majelis Pengawas Notaris Tingkat kabupaten/kota, Pada tanggal 20 April 2018 .

Hasil wawancara langsung dengan Ibu Neliwati.S.H.,M.H selau ketua Majelis Pengawas Daerah (MPD) kota Palembang, tanggal 23 Mei 2018. 